\title{
Carcass Characteristics of the Libyan Purebred Mahali Goat and their Crosses with Damascus and Morcia Granada Goats
}

\author{
Abdelkareem E. Ahtash ${ }^{1 *}$, Abdulla S. Biala ${ }^{1}$, Aiad F. Magid ${ }^{1}$ \\ and Hamed M. Marhoun ${ }^{2}$ \\ ${ }^{1}$ Department of Animal Production, Faculty of Agriculture, \\ Al-Fateh University, Tripoli, Libya \\ ${ }^{2}$ Department of Animal Production, Faculty of Agriculture, \\ Omar Mokhtar University, Al-Bayda, Libya
}
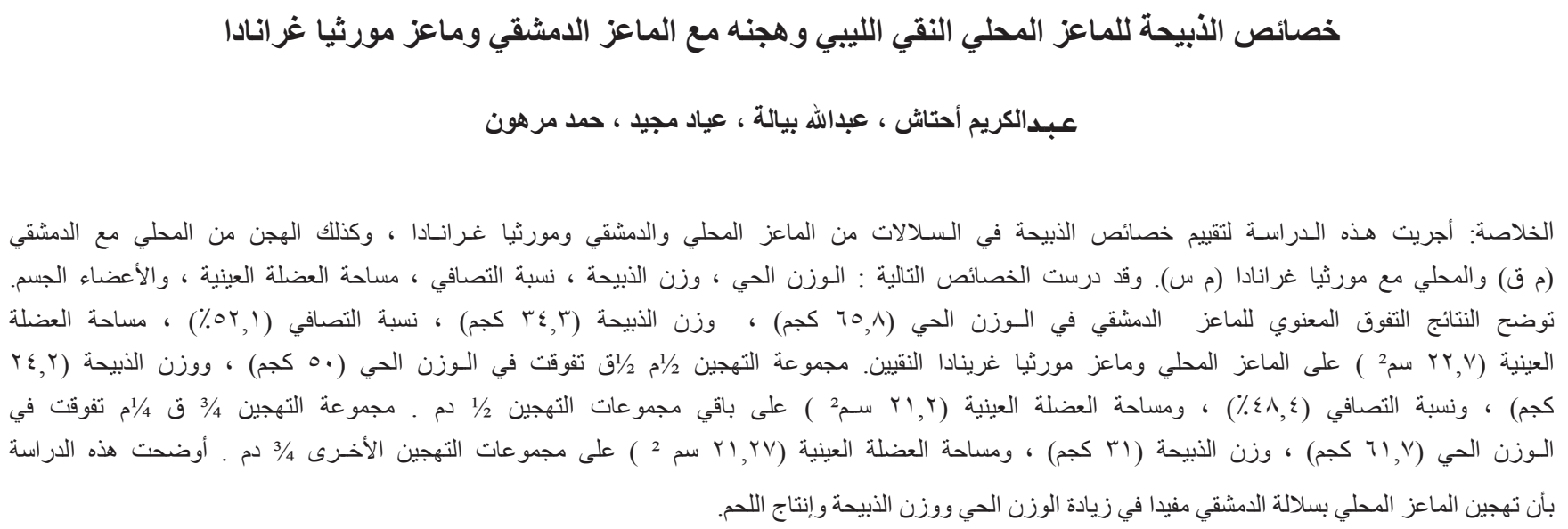

ABSTRACT: This study was conducted to evaluate the carcass characteristics of Mahali (M), Damascus (D) and Morcia Granada (G) goats and their crosses. Live weight, carcass weight, dressing-out \%, rib eye muscle area, non-carcass components and kidney fat were measured. The results showed significant superiority of Damascus goats in live weight $(65.8 \mathrm{~kg})$, carcass weight $(34.3 \mathrm{~kg})$, dressing-out \%( $52.1 \%)$, rib eye muscle areas $\left(22.7 \mathrm{~cm}^{2}\right)$ over the Mahali and Morcia Granada goats. The crossbred group $(1 / 2 \mathrm{M} \mathrm{x} \mathrm{1/2} \mathrm{D)} \mathrm{was} \mathrm{superior} \mathrm{in} \mathrm{live} \mathrm{weight} \mathrm{(50}$ $\mathrm{kg}$ ), carcass weight $(24.2 \mathrm{~kg})$, dressing-out $\%(48.4 \%)$, and rib eye muscle area $\left(21.2 \mathrm{~cm}^{2}\right)$ over other crossbreds. The crossbred group $(3 / 4 \mathrm{D} x$ $1 / 4 \mathrm{M})$ was superior in live weight $(61.7 \mathrm{~kg})$, carcass weight $(31 \mathrm{~kg})$ and rib eye muscle area $\left(21.3 \mathrm{~cm}^{2}\right)$ over the other $3 / 4$ crossbreds. This study indicated that crossing between Mahali x Damascus breed was beneficial for increasing live weight, carcass weight and meat production.

Keywords: Bbeeds, crossbreeding, carcass.

\section{Introduction}

Goat production is one of the most important animal production activities in Libya. It represents the second rank in livestock population after sheep (Ahtash, 2006). The relative importance of goat as compared to livestock comprises 20$22 \%$ of the total animal unit during the period 1990-2004. The goat population in Libya ranged between 1.5-2.0 million heads and $90 \%$ of this number represents the local goat breed (Mahali) which is distributed around the coastal area of Libya.

Extensive production is the main system used for goat production in Libya, where they are raised either independently or in the form of mixed flocks with sheep.
They are also raised on a large scale with a small number of animals in rural regions. Mahali goats are considered to be as dual purpose animal (meat and milk). The Mahali goat contributed about $12.3 \%$ of the total meat production in 1966 , however, with meat of sheep the contribution reached $30 \%$ by year 2000 (Ahtash, 2006). Shreha (1989) reported that as per capita the contribution of goat meat estimated to be around $33.6 \%$ of total red meat consumed in Libya. Magid et al. (1984) and Magid (1995) showed that the Mahali goat was lower in productivity compared to other breeds. The average live body weights of Mahali goat at weaning and 7 month of age were 9.9 and $16 \mathrm{~kg}$, respectively, while dressing-out \% at 
7, 10, 12 months of age were $46 \%, 52 \%, 49 \%$, respectively (Magid, 1987). Damascus and Morcia Granada goat breeds were therefore, imported for crossing with Mahali goats to improve its low productivity. The main objective of this study was to evaluate carcass characteristics of Mahali goat and their crosses with Damascus and Morcia Granada goats.

\section{Materials and Methods}

\section{Location}

The study was conducted in Bir-Elghanem Research Station (south west of Tripoli) under the authority of Animal Wealth Research Center. The region is classified as semi-arid, and characterized by rainy winter and dry summer. The ambient air temperature ranges from $9-42^{\circ} \mathrm{C}$ and the relative humidity between $63-81 \%$ with annual precipitation between $190-350 \mathrm{~mm}$.

\section{Flock Management}

Intensive close system was practiced at Bir-Elghanem station, the animals were raised under half-opened yard, and the water was available ad-libitum. The average quantity of concentrate was $0.5-1.0 \mathrm{~kg} / \mathrm{head} / \mathrm{day}$, and the roughages ranged $1.0-1.5 \mathrm{~kg} / \mathrm{head} /$ day.

\section{Carcass Evaluation}

Thirty-eight bucks at 14 month age were randomly selected for carcass evaluation. These bucks belong to 10 breeding groups that represents three pure goat breeds
[Mahali (M), Damascus (D) and Morcia Granada (G)], first crosses generation ( $\mathrm{MxD}, \mathrm{D} \times \mathrm{M}, \mathrm{Mx}$ G and $\mathrm{G} \times \mathrm{M}$ ) and second crosses generation $[3 / 4 \mathrm{M} \times 1 / 4 \mathrm{D}, 3 / 4 \mathrm{D} \times 1 / 4 \mathrm{M}$ and $3 / 4 \mathrm{M}$ $\mathrm{X} 1 / 4 \mathrm{G}]$. The animals were fastened for $24 \mathrm{hrs}$ and weighed prior to slaughter. The weights of carcass, head, legs, skin, empty rumen, intestine, kidney, heart, spleen, kidney fat, abdominal fat, and Longissimus eye muscle area were recorded.

\section{Statistical Analysis}

Statistical analyses were carried out using analysis of variance producers (SAS, 1998) to evaluate the effect of breed and their crossing on carcass characteristics. Carcass characteristics were analyzed for the fixed effect, where the model used included the effect of breeding group on all carcass characters. Duncan's multiple range tests was used to test the significance of difference among least square means.

\section{Results and Discussion}

The results showed significant effect of breeding group on all traits studied except omental and mesenteric fat weights.

\section{Live and Slaughter Weights and Dressing \%}

The results showed that breeding group had highly significant $(\mathrm{P}<0.01)$ effect on live and slaughter weight and dressing \% (Table 1). The Damascus goat breed is superior in live weight, slaughter weight and dressing \% when compared to the other pure and crossbred groups.

Table 1. Least squares means \pm S.E. of live weight $(\mathrm{kg})$, slaughter weight $(\mathrm{kg})$ and dressing $\%$ of kids in breeding groups.

\begin{tabular}{|c|c|c|c|c|}
\hline $\begin{array}{l}\text { Trait } \\
\text { S.V }\end{array}$ & No. & $\begin{array}{l}\text { Live weight } \\
(\mathrm{kg})\end{array}$ & $\begin{array}{c}\text { Slaughter weight } \\
(\mathrm{kg})\end{array}$ & Dressing (\%) \\
\hline Breeding group & & $* *$ & $* *$ & $* *$ \\
\hline DD & 4 & $65.8 \pm 2.2^{\mathrm{a}}$ & $34.3 \pm 1.13^{\mathrm{a}}$ & $52.1 \pm 0.9^{\mathrm{a}}$ \\
\hline MM & 3 & $38.8 \pm 2.5^{\mathrm{cd}}$ & $19.0 \pm 1.31^{\mathrm{cd}}$ & $48.9 \pm 1.1 \mathrm{bc}$ \\
\hline GG & 4 & $33.6 \pm 2.2^{\mathrm{d}}$ & $16.3 \pm 1.13^{\mathrm{d}}$ & $48.0 \pm 0.9 \mathrm{bc}$ \\
\hline $1 / 2 \mathrm{M}^{1 / 2} \mathrm{D}$ & 4 & $50.0 \pm 2.2^{b}$ & $24.2 \pm 1.13^{b}$ & $48.4 \pm 0.9^{\mathrm{bc}}$ \\
\hline $1 / 2 \mathrm{D}^{1} / 2 \mathrm{M}$ & 4 & $48.0 \pm 2.2^{b}$ & $22.4 \pm 1.13^{b c}$ & $46.7 \pm 0.9^{\mathrm{c}}$ \\
\hline $1 / 2 \mathrm{M}^{1 / 2} \mathrm{G}$ & 4 & $34.2 \pm 2.2 \mathrm{~d}$ & $16.3 \pm 1.13^{d}$ & $47.5 \pm 0.9^{\mathrm{bc}}$ \\
\hline $1 / 2 \mathrm{G}^{1} / 2 \mathrm{M}$ & 4 & $40.2 \pm 2.2^{\mathrm{cd}}$ & $19.1 \pm 1.13^{\mathrm{cd}}$ & $47.4 \pm 0.9 \mathrm{bc}$ \\
\hline $3 / 4 \mathrm{M}^{1 / 4} \mathrm{D}$ & 4 & $44.4 \pm 2.2^{b c}$ & $22.1 \pm 1.13^{b c}$ & $50.3 \pm 0.9^{\mathrm{ab}}$ \\
\hline $3 / 4 \mathrm{D}^{1} / 4 \mathrm{M}$ & 4 & $61.7 \pm 2.2^{\mathrm{a}}$ & $31.0 \pm 1.13^{\mathrm{a}}$ & $50.1 \pm 0.9^{a b c}$ \\
\hline $3 / 4 \mathrm{M}^{1 / 4} \mathrm{G}$ & 3 & $40.3 \pm 2.5^{\mathrm{cd}}$ & $19.3 \pm 1.31^{\mathrm{cd}}$ & $47.9 \pm 1.1^{\mathrm{bc}}$ \\
\hline Average mean & & $46.1 \pm 1.8$ & $22.6 \pm 1.01$ & $48.8 \pm 0.4$ \\
\hline
\end{tabular}

$* *: \mathrm{P}<0.01$

Means with same letters in the same column, do not differ significantly.

Goat breeds: M: Mahali; D: Damascus; G: Morcia Granada (G) 
The average live weight, slaughter weight and dressing $\%$ of pure Damascus were $65.8 \mathrm{~kg}, 34.3 \mathrm{~kg}$ and $52.1 \%$, respectively. Whereas, the average of the same traits in Mahali were $38.8 \mathrm{~kg}, 19 \mathrm{~kg}$ and $48.9 \%$ and for Morcia Granada were $33.6 \mathrm{~kg}, 16.3 \mathrm{~kg}$ and $48 \%$. The dressing percentage of Mahali goat in this study was in agreement with that recorded by Biala et al. (1999) in their study with the same breed where they found the dressing \% was $49 \%$. While the dressing \% of Damascus goat was $49.9 \%$ as reported by Shaker et al. (1985), which was lower than that obtained in this study, Aboul-Naga, (1984) reported a significant effect of breed on live weight of Barki goat and $1 / 2$ Shami $1 \frac{1}{2}$ Barki at an age of 8 months. The average live weight of Mahali goat in this study was greater than that reported by Biala et al. (1999) which was $33 \mathrm{~kg}$ at 13 months of age. It is obvious from Table 1 that the crosses of Mahali with Damascus had the highest live weight, slaughter weight and dressing \% compared to the crossbred of Mahali with Morcia Granada, which reflects the great growth potentiality of Damascus breed in comparison with Morcia Granada breed. The average live weight, slaughter weight and dressing $\%$ of the Crossbred $3 / 4 \mathrm{D}^{1 / 4 \mathrm{M}}$ were $61.7 \mathrm{~kg}, 31 \mathrm{~kg}$ and $50.1 \%$, respectively. These values were not significantly different from values obtained by the purebred Damascus goat. The crossbred $1 / 2 \mathrm{M}^{1 / 2} \mathrm{D}$ and $1 / 2 \mathrm{D}^{1 / 2} \mathrm{M}$ differ significantly $(\mathrm{P}<0.01)$ in live weight, slaughter weight and dressing $\%(50 \mathrm{~kg}, 24.2 \mathrm{~kg}$, $48.4 \%$ and $48 \mathrm{~kg}, 22.4 \mathrm{~kg}, 46.7 \%$ in respective order) from the purebred Damascus and Mahali goats. The crossbred of Mahali with Morcia Granada $\left(1 / 2 \mathrm{M}^{1} / 2 \mathrm{G}\right)$ showed the lowest live weight and slaughter weight compared with other crossbred groups, however, it was not significantly different from both pure breeds ( $M$ and $G$ ). This indicates the inferiority of the Morcia Granada breed to improve meat production. These results were in agreement with the study of Abdelsalam et al. (1994) who found that the body weight of crossbred Damascus X Barki kids was intermediate between those of their purebred parents. Abdelsalam et al. (2000) reported that the Damascus breed sired Barki goats produced a heavier litter and the crossbred exceeded the Barki in milk yield and litter weight. Al-Ojaili (1995) concluded that crossbreeding of Dhofari goats with a temperate breed (Anglo-Nubian) was beneficial for increasing meat production in Oman. Misra (1983) evaluated kids of the Black Bengal, Jamunapari and Beetal breeds and their crosses; they concluded that the large breeds have potential merit for improving meat production in small and medium sized goat breeds in India. In his study with Spanish goats and their cross with the Boer goat breed. Oman et al. (1999) found that the crossbred was greater in live weight than Spanish goat breed. The results obtained by Mia et al. (1993) in their study with different breeds (Black Bengal, Barbari and Anglo-Nubian, and Barbari Black Bengal cross) showed that the body weight of crossbred kids remained intermediate to kids of their purebred parents. Mioc et al. (2001) reported a significant difference in dressing \% due to the difference in breeds. It was shown that with an increase in body weight the dressing \% increased (Dhanda et al., 2003).

The half bred groups from Mahali with both Damascus and Morcia Granada did not differ significantly; however, $1 / 2 \mathrm{D}^{1 / 2} \mathrm{M}$ had the lowest dressing \% (46.7\%). The hybrid groups $3 / 4 \mathrm{M}^{1} 1 / 4 \mathrm{D}$ and $3 / 4 \mathrm{D}^{1} / 4 \mathrm{M}$ had a higher dressing percentage (50.3 and $50.1 \%$, respectively) than the half bred groups, although the difference was not significant. The differences among crossing groups in dressing $\%$ could be referred to the difference of the stomach and intestine content at time of slaughtering (Van Niekerk and Casey, 1998).

\section{Rib Eye Muscle Areas}

A highly significant effect of breeding groups $(\mathrm{P}<0.01)$ on rib eye muscle areas was found. As shown in Table 2, the Damascus goat had the greatest rib eye muscle areas (22.7 $\left.\mathrm{cm}^{2}\right)$, while the Mahali goat had the lowest one $\left(14.4 \mathrm{~cm}^{2}\right)$ and the Morcia Granada breed was intermediate in this trait $\left(18.7 \mathrm{~cm}^{2}\right)$. The half-bred of Mahali with Damascus goats was superior in this trait among half-bred of Mahali with Morcia Granada, the same trend is found with $3 / 4 \mathrm{D}^{1 / 4} \mathrm{M}$ crossbred. It is obvious that this trait was improved in Mahali goats by crossbreeding with the Damascus goat breed. The variation in rib eye muscle areas resulted from the differences in live weight of crossing groups (Kadim et al., 2003). The authors found in their study of three Omani breeds, that the green mountain goat had the greatest rib eye muscle areas $\left(130 \mathrm{~mm}^{2}\right)$ compared with Dhofari breed $\left(119 \mathrm{~mm}^{2}\right)$ and Batina breed ( 106 $\mathrm{mm}^{2}$ ). Oman et al. (2000) reported that Angora kids had significantly smaller longissimus muscle area compared to Spanish, Boer x Spanish and Spanish x Angora kids.

\section{Edible Parts, Kdney and Spleen Weight}

Table 2 shows the significant effect of crossing group $(\mathrm{P}<0.01)$ on edible parts, kidney and spleen weights. Damascus goat breed exceeded $(2.43 \mathrm{~kg})$ the pure breed of Mahali and Morcia Granada goat on edible parts weight (1.41 kg and $1.31 \mathrm{~kg}$ respectively). Half bred of Mahali with Damascus goats and $3 / 4 \mathrm{D}^{1} / 4 \mathrm{M}$ crossbred were superior on edible parts weight compared with $1 / 2 \mathrm{M}^{1} / 2 \mathrm{D}$ and $3 / 4 \mathrm{M}^{1 / 4} \mathrm{G}$. Results reflect the influence of large live body weight of the Damascus breed among the other breeds. Edible parts expressed as a percentage of carcass empty weight for Damascus, Mahali and Morcia Granada were $3.91 \%, 3.9 \%$ and $4.23 \%$ respectively. Wahid et al. (1985) reported differences on edible parts weight due to crossing that affects live weight. The results of this study were in agreement with the study of Mioc et al. (2001) who found a significant effect of breed $(\mathrm{P}<0.05)$ on edible parts weight, where the Alpine goat exceeded the Sannen breed on this trait.

The same trend was found with kidney and spleen weight, where the Damascus purebred and $3 / 4 \mathrm{D}^{1 / 4} \mathrm{M}$ crossbred goat had the heaviest weight of kidney compared 
Table 2. Least squares means \pm S.E. for rib muscle area $\left(\mathrm{cm}^{2}\right)$, edible parts $(\mathrm{kg})$, kidney weight $(\mathrm{kg})$ and spleen weight (g) of kids in breeding groups.

\begin{tabular}{|c|c|c|c|c|c|}
\hline $\begin{array}{l}\text { Trait } \\
\text { S.V }\end{array}$ & No. & Rib muscle area $\left(\mathrm{cm}^{2}\right)$ & Edible parts $(\mathrm{kg}) \delta$ & Kidney weight (g) & Spleen weight (g) \\
\hline Breeding group & & $* *$ & $* *$ & $* *$ & $* *$ \\
\hline $\mathrm{DD}$ & 4 & $22.7 \pm 1.3^{\text {a }}$ & $2.43 \pm 0.07^{\mathrm{a}}$ & $175.0 \pm 6.9^{\mathrm{a}}$ & $112.5 \pm 7.8^{\text {a }}$ \\
\hline MM & 3 & $14.4 \pm 1.5^{\mathrm{d}}$ & $1.41 \pm 0.08 \mathrm{de}$ & $101.6 \pm 7.9^{\mathrm{cd}}$ & $41.6 \pm 9.0^{\mathrm{d}}$ \\
\hline GG & 4 & $18.7 \pm 1.3^{\mathrm{abc}}$ & $1.31 \pm 0.07^{\mathrm{e}}$ & $118.8 \pm 6.9 \mathrm{bc}$ & $56.3 \pm 7.8^{\mathrm{bcd}}$ \\
\hline $1 / 2 \mathrm{M}^{1} / 2 \mathrm{D}$ & 4 & $21.2 \pm 1.3^{\mathrm{ab}}$ & $1.86 \pm 0.07^{\mathrm{c}}$ & $137.5 \pm 6.9^{b}$ & $62.5 \pm 7.8^{\mathrm{bcd}}$ \\
\hline $1 / 2 \mathrm{D}^{1} / 2 \mathrm{M}$ & 4 & $20.7 \pm 1.3 \mathrm{abc}$ & $1.76 \pm 0.07^{\mathrm{c}}$ & $131.2 \pm 6.9^{b}$ & $68.8 \pm 7.8^{\mathrm{bc}}$ \\
\hline $1 / 2 \mathrm{M}^{1 / 2} \mathrm{G}$ & 4 & $16.3 \pm 1.3^{\mathrm{cd}}$ & $1.30 \pm 0.07^{\mathrm{e}}$ & $87.5 \pm 6.9^{\mathrm{d}}$ & $49.2 \pm 7.8^{\mathrm{cd}}$ \\
\hline $1 / 2 \mathrm{G}^{1} / 2 \mathrm{M}$ & 4 & $17.6 \pm 1.3^{\mathrm{bcd}}$ & $1.51 \pm 0.07 \mathrm{de}$ & $137.5 \pm 6.9^{b}$ & $68.7 \pm 7.8^{b c}$ \\
\hline $3 / 4 \mathrm{M}^{1 / 4} \mathrm{D}$ & 4 & $17.8 \pm 1.3^{\text {bcd }}$ & $1.60 \pm 0.07^{\mathrm{cd}}$ & $137.5 \pm 6.9^{b}$ & $81.2 \pm 7.8^{b}$ \\
\hline $3 / 4 \mathrm{D}^{1} / 4 \mathrm{M}$ & 4 & $21.3 \pm 1.3 \mathrm{ab}$ & $2.18 \pm 0.07^{b}$ & $156.2 \pm 6.9^{\text {a }}$ & $81.2 \pm 7.8^{b}$ \\
\hline $3 / 4 \mathrm{M}^{1 / 4} \mathrm{G}$ & 3 & $20.4 \pm 1.5^{\mathrm{abc}}$ & $1.63 \pm 0.08^{\mathrm{cd}}$ & $125.0 \pm 7.9^{b}$ & $66.6 \pm 9.0^{\mathrm{bcd}}$ \\
\hline Average mean & & $19.2 \pm 0.5$ & $1.71 \pm 0.06$ & $131.7 \pm 4.4$ & $69.7 \pm 3.8$ \\
\hline
\end{tabular}

$* *: \mathrm{P}<0.01$

Means with same letters in the same column, do not differ significantly.

Goat breeds: M: Mahali; D: Damascus; G: Morcia Granada (G)

$\delta$ edible parts $=$ heart, liver and lung weights.

with Mahali and the Morcia Granada. The heaviest spleen weight recorded on Damascus purebred, $3 / 4 \mathrm{D}^{1 / 4 \mathrm{M}}$ and $3 / 4 \mathrm{M}^{1} / 4 \mathrm{D}$ crossbred compared with other purebred and crossbred groups. Mahali and Morcia Granada goats did not differ significantly in the weight of both kidney and spleen. This finding was in agreement with the study of Shaker and Masry (1983), who reported the significant effect of crossing groups on kidney weight. The variation in the kidney and spleen weight could be due to differences in slaughter weight (Dhanda et al., 2003).

\section{Stomach and Intestine Weights}

Results show the significant effects $(\mathrm{P}<0.01)$ of breeding group on stomach and intestine weights (Table 3$)$. There is

Table 3. Least squares means \pm S.E. for stomach and intestine weight $(\mathrm{kg})$, weight of fat around the stomach and intestine $(\mathrm{g})$ and weight of fat around the kidney of kids in breeding groups.

\begin{tabular}{|c|c|c|c|c|}
\hline $\begin{array}{l}\text { Trait } \\
\text { S.V }\end{array}$ & No. & Stomach and intestine $(\mathrm{kg})$ & $\begin{array}{l}\text { Fat around stomach and } \\
\text { intestine }(\mathrm{g})\end{array}$ & Fat around kidney $(\mathrm{g})$ \\
\hline Breeding group & & $* *$ & ns & $*$ \\
\hline DD & 4 & $4.7 \pm 0.2^{\mathrm{a}}$ & $793.8 \pm 170.7^{\mathrm{a}}$ & $375.0 \pm 83.3^{b}$ \\
\hline MM & 3 & $2.9 \pm 0.23^{\mathrm{cd}}$ & $783.3 \pm 197.1^{\mathrm{a}}$ & $133.3 \pm 96.2 c$ \\
\hline GG & 4 & $2.9 \pm 0.2^{\mathrm{cd}}$ & $550.0 \pm 170.7^{\text {a }}$ & $112.5 \pm 83.3 \mathrm{c}$ \\
\hline $1 / 2 \mathrm{M}^{1} / 2 \mathrm{D}$ & 4 & $3.9 \pm 0.2^{b}$ & $737.5 \pm 170.7^{\mathrm{a}}$ & $337.5 \pm 83.3^{b}$ \\
\hline $1 / 2 \mathrm{D}^{1 / 2 \mathrm{M}}$ & 4 & $3.3 \pm 0.2^{c}$ & $712.5 \pm 170.7^{a}$ & $325.0 \pm 83.3^{b}$ \\
\hline $1 / 2 \mathrm{M}^{1 / 2} \mathrm{G}$ & 4 & $2.4 \pm 0.2^{\mathrm{d}}$ & $650.0 \pm 170.7^{a}$ & $231.2 \pm 83.3 \mathrm{c}$ \\
\hline $1 / 2 \mathrm{G}^{1} / 2 \mathrm{M}$ & 4 & $3.0 \pm 0.2^{\mathrm{cd}}$ & $975.0 \pm 170.7^{\mathrm{a}}$ & $475.0 \pm 83.3^{\mathrm{a}}$ \\
\hline $3 / 4 M^{1 / 4} \mathrm{D}$ & 4 & $3.1 \pm 0.2^{\mathrm{c}}$ & $762.5 \pm 170.7^{\mathrm{a}}$ & $387.5 \pm 83.3^{b}$ \\
\hline $\begin{array}{l}3 / 4 \mathrm{D}^{1 / 4 \mathrm{M}} \\
3 / 4 \mathrm{M}^{1 / 4} \mathrm{G}\end{array}$ & $\begin{array}{l}4 \\
3\end{array}$ & $\begin{array}{c}4.0 \pm 0.2^{b} \\
3.1 \pm 0.23^{c}\end{array}$ & $\begin{array}{l}987.5 \pm 170.7^{\mathrm{a}} \\
833.0 \pm 197.1^{\mathrm{a}}\end{array}$ & $\begin{array}{l}362.5 \pm 83.3^{b} \\
391.6 \pm 96.2^{b}\end{array}$ \\
\hline Average mean & & $3.4 \pm 0.12$ & $776.9 \pm 52.7$ & $315.8 \pm 29.6$ \\
\hline
\end{tabular}

ns $=$ non signifiant: $\mathrm{P}>0.05 ; *: \mathrm{P}<0.05 ; * *: \mathrm{P}<0.01$

Means with same letters in the same column, do not differ significantly.

Goat breeds: M: Mahali; D: Damascus; G: Morcia Granada (G) 
Table 4. Least squares mean \pm S.E. for head legs and hide weight $(\mathrm{kg})$ of kids in breeding groups.

\begin{tabular}{|c|c|c|c|c|}
\hline $\begin{array}{l}\text { Trait } \\
\text { S.V }\end{array}$ & No. & head weight ( $\mathrm{kg}$ ) & legs weight $(\mathrm{kg})$ & Hide weight $(\mathrm{kg})$ \\
\hline Breeding group & & $* *$ & $* *$ & $* *$ \\
\hline $\mathrm{DD}$ & 4 & $4.3 \pm 0.14^{\mathrm{a}}$ & $1.71 \pm 0.10^{\mathrm{a}}$ & $5.10 \pm 0.20^{\mathrm{a}}$ \\
\hline MM & 3 & $2.6 \pm 0.17 \mathrm{~cd}$ & $0.91 \pm 0.12^{\mathrm{d}}$ & $2.65 \pm 0.23 \mathrm{ef}^{-}$ \\
\hline GG & 4 & $2.5 \pm 0.14^{\mathrm{d}}$ & $1.03 \pm 0.10^{\mathrm{cd}}$ & $2.05 \pm 0.20^{\mathrm{f}}$ \\
\hline $1 / 2 \mathrm{M}^{1} / 2 \mathrm{D}$ & 4 & $3.4 \pm 0.14^{b}$ & $1.28 \pm 0.10^{b c}$ & $3.70 \pm 0.20^{\mathrm{c}}$ \\
\hline $1 / 2 D^{1 / 2} \mathrm{M}$ & 4 & $3.4 \pm 0.14^{b}$ & $1.24 \pm 0.10^{\mathrm{bc}}$ & $3.45 \pm 0.02^{\mathrm{cd}}$ \\
\hline $1 / 2 \mathrm{M}^{1} / 2 \mathrm{G}$ & 4 & $2.4 \pm 0.14^{\mathrm{d}}$ & $0.83 \pm 0.10^{d}$ & $2.47 \pm 0.20$ ef \\
\hline $1 / 2 \mathrm{G}^{1} / 2 \mathrm{M}$ & 4 & $2.7 \pm 0.14^{\mathrm{cd}}$ & $0.91 \pm 0.10^{\mathrm{d}}$ & $2.58 \pm 0.20^{\text {ef }}$ \\
\hline $3 / 4 \mathrm{M}^{1} / 4 \mathrm{D}$ & 4 & $3.1 \pm 0.14^{\mathrm{bc}}$ & $1.13 \pm 0.10^{\mathrm{cd}}$ & $3.00 \pm 0.20^{\mathrm{de}}$ \\
\hline $3 / 4 \mathrm{D}^{1 / 4} \mathrm{M}$ & 4 & $4.0 \pm 0.14^{\mathrm{a}}$ & $1.50 \pm 0.10^{\mathrm{ab}}$ & $4.40 \pm 0.20^{b}$ \\
\hline $3 / 4 \mathrm{M}^{1} / 4 \mathrm{G}$ & 3 & $2.8 \pm 0.17^{\mathrm{cd}}$ & $1.05 \pm 0.12^{\mathrm{cd}}$ & $2.58 \pm 0.23$ ef \\
\hline Average mean & & $3.2 \pm 0.11$ & $1.17 \pm 0.05$ & $3.25 \pm 0.16$ \\
\hline
\end{tabular}

** : $\mathrm{P}<0.01$

Means with same letters in the same column, do not differ significantly. Goat breeds: M: Mahali; D: Damascus; G: Morcia Granada (G)

a clear superiority of Damascus breed goats with regards to these traits $(4.7 \mathrm{~kg})$ over the other pure and cross bred groups. Crossbred $1 / 2 \mathrm{M}^{1 / 2} \mathrm{D}$ and $3 / 4 \mathrm{D}^{1 / 4} \mathrm{M}$ did not differ in these traits and were $3.9 \mathrm{~kg}$ and $4.0 \mathrm{~kg}$ respectively. The other crossbred groups had the lowest stomach and intestine weights among crossing groups. Fat around stomach and intestine did not differ significantly due to the effects of breeding groups (Table 3). The greatest weight of stomach and intestine obviously correlated with breed size, hence the Damascus goat had the greatest live weight among the other pure and crossbred groups. It was concluded that the increase in weight of stomach, intestine and fat around these parts is related to the increase in slaughter weight (Economides and Olymbios, 1991).

\section{Weight of fat around stomach, intestine and kidney}

Though differences among crossing groups on weight of fat around stomach and intestine were not significant $(\mathrm{P}>0.05)$, the fat weight around stomach and intestine ranged between $550-793.8$ gm on pure breeds $(M, D, G)$, $650-975 \mathrm{gm}$ on half-bred groups and $762.5-987.5 \mathrm{gm}$ on three-quarter crossing groups. Fat around stomach and intestine as a percentage of empty weight ranged between $1.26-2.53 \%$. These results were in agreement with the study of Pralomkarm et al. (1995), who reported using local Thailand goats and their crosses with the AngloNubian breed and the non-significant differences between crossing groups on fat weight around stomach and intestine. Fat weight around kidney differs significantly among breeding groups $(\mathrm{P}<0.05)$. Damascus goats had the highest fat around kidney (375 gm) compared with pure bred Mahali and Morcia-Granada breeds (133 gm and 112.5 gm respectively), while the half-bred groups ranged between 231 - $475 \mathrm{gm}$. Three-quarter crossing groups did not differ significantly on fat around kidney and they ranged between 362-391 gm. Mahgoub and Lu (1998) studied two different goat breeds, they found significant superiority of Dhofari goats on fat weight around kidney among Omani Batina. Differences on fat weight around kidney were caused by the variation on live weight due breeding groups effect (Treacher et al., 1987).

\section{Carcass By Products}

Head, legs and hide represents the largest part of carcass by products which affect slaughter weight and dressing $\%$. Increasing the weight of those residuals was accompanied by a reduction on dressing $\%$ and carcass weight. The Damascus goats and $3 / 4 \mathrm{D}^{1 / 4} \mathrm{M}$ had the largest weight of head, legs and hide (Table 4), and they differ significantly from other crossing groups. In general, Mahali and Morcia Granada breeds have the lowest weight of head, legs and hide, the same trend found on the different crosses of Mahali with Morcia Granada in comparison with the different crosses of Mahali with Damascus breeds. Although the head weight of Damascus was larger than other pure breed, but represent the lowest as a percentage of empty weight of carcass $(6.86 \%)$. It is obvious from these results that increasing crossing of Mahali with the Damascus breed increased the weight of head, legs and hide while it decreased with crosses of Mahali with Morcia 
Granada. Breed effects were significant on head and hide as a percentage of body weight (Amin et al., 2000). However, Johnson et al. (1995) reported a non significant effect of breeding groups on legs as a percentage of body weight.

\section{Conclusion}

It is concluded that crossbreeding of Mahali goat with Damascus breed improved growth rate of the indigenous goats, and the breed crosses demonstrated an advantage in carcass characteristics mainly due to large live body weight and good growth rate. However, there is a need for further studies to evaluate other economically important traits in different crossbreds raised under different goat production systems. The large Damascus breed has a potential merit for improving meat production by medium-sized Mahali breed in Libya.

\section{References}

Abdelsalam, M.M., A.E. Haider, A.M. Aboul-Naga, I.S. El-Kimary and M. Eissa. 1994. Improving performance of desert Barki kids by crossing with Zaraibi and Damascus goats. Egyptian Journal of Animal Production 31:85-97.

Abdelsalam, M.M., M. Eissa, G. Maharam, A.I. Haider. 2000. Improving the productivity of Barki goat by crossbreeding with Damascus or Zaraibi breeds. Alexandria Journal of Agricultural Research 45:33-42.

Aboul-Naga, A.M. 1984. Small ruminants in the near East. Vol.1. A.W. Qureshi and H.A. Fitzhugh (Editors), FAO 1987.

Ahtash, A. 2006. Goat production. In: Proceeding of Regional Workshop on Recent Advances in Goat Production Under Arid Condition. H.M. El-Shaer, Talib M. Ali Elam and A. Mehrez (Editors), 310-316. Desert Research Center and FAO, Cairo, Egypt.

Al-Ojaili, A.A. 1995. Production traits in Dhofari and Dhofari $\times$ Anglo-Nubian goats in Oman. International Journal of Animal Science 10:13-16.

Amin, M.R., S.S. Husain and A.B.M.M. Islam. 2000. Evaluation of Black Bengal goats and their cross with Jamnapari breed for carcass characteristics. Small Ruminant Research 38:211-215.

Biala, A.S., A.F. Magid, M.Y. Masry, and S.K. Salem. 1999. Meat characteristics of some goat breeds in Jamahiriya. Agriculture Research Journal 5:32-45. (In Arabic).

Dhanda, J.S., D.G. Taylor and P.J. Murray. 2003. 1Growth, carcass and meat quality parameters of male goats: effects of genotype and live weight at slaughter. Small Ruminant Research 50:57-66.

Economides, S. and S. Olymbios. 1991. The effect of slaughter weight on carcass merit and conversion of milk or solid feed to meet in Damascus goats. Agricultural Research Institute, Ministry of Agriculture and Natural Resources, Nicosia (Cyprus). 11pp.
Johnson, D.D., C.H. Mc.Gowan, G. Hurse and M.R. Anous.1995. Breed type and sex effects on carcass traits, composition and tenderness of young goats. Small Ruminant Research 17:57-63.

Kadim, I.T., O. Mahgoub, D.S. Al-Ajmi, R.S. Al-Maqbaly, N.M. Al-Saqri and A. Ritchie. 2003. An evaluation of the growth, carcass and meat quality characteristics of Omani goat breeds. Meat Science 66:203-210.

Mahgoub, O. and C.D. Lu. 1998. Growth, body composition and carcass tissue distribution in goats of large and small size. Small Ruminant Research 27: 267-278.

Magid, A.F. 1987. Results of primary stage of studying production traits for local goats. Report presented for Agriculture Research Center include studying of growth rate, mortality, fertility, puberty, goat's forage digestibility. Agricultural Research Center. (In Arabic).

Magid, A.F. 1995. Types of sheep and goat breeding on Jamahiriya. Food Security Proceeding 1. Faculty of Agriculture/Al-Fateh University-Tripoli, 16-18/10/ 1995. (In Arabic).

Magid, A.F., A. Aboubaker, H. Mabrouk, A. Rahal, A. Ghomati and A. Shreha. 1984. Goat production on Jamahiriya (Preliminary study). National Scientific Research Academy and Agricultural Research Center. (In Arabic).

Mia, M.M., A. Ali and M.A.R. Howlider. 1993. Growth performance of Black Bengal, Barbari, Anglo-Nubian and Barbari $\times$ Black Bengal goats. Indian Journal of Animal Science 63:1214-1215.

Mioc, B., V. Pavic and A. Ivankovic. 2001. Some carcass traits and chemical composition of different muscle groups in Alpine and Sannen kids. Journal of Animal Science 46:83- 87.

Misra, R.K. 1983. Genetic analysis of growth, survivability, efficiency of feed conversion and carcass yield and composition in Sirohi (goat) and its crosses with Beetal. Ph.D. thesis. University Kurukshetra, Haryana, India, 152pp.

Oman, J.S., D.F. Waldron, D.B. Griffin and J.W. Savell. 1999. Effect of breed- type and feeding regimen on goat carcass traits. Journal of Animal Science 77: 3215-3218

Pralomkarn, W., S. Saithanoo, S. Kochapakdee and B.W. Norton. 1995. Effect of genotype and plane of nutrition on carcass characteristics of Thai native and AngloNubian x Thai native male goats. Small Ruminant Research 16:21-25.

SAS. 1998. SAS User' Guides: Statistics. Ver. 6.12. SAS Inst., Cary, NC.

Shaker, B., M. Dsouki, T. Hamoud and A. Al-Sayed. 1985. Primary experiment for fattening Shami male goats. Ministry of Agriculture on Syria Arabic Republic. Goat Resources on Arab Country. ACSAD. (In Arabic).

Shaker, B. and A. Masry. 1983. A study of qualitative traits and some productive traits on Gabli goat and 
their crosses with Shami goat. Goat Resources on Arabic Country, Syria Arabic Republic. ACSAD. (In Arabic).

Shreha, A. 1989. Horizones of Animal Wealth on Jamahiriya. Camels Research Center. (In Arabic).

Treacher, T.T., A. Mowlem, R.M. Wilde and B. ButlerHogg. 1987. Growth efficiency and carcass composition of castrated male Sannen and Sannen -Angora kids on a concentrate diet. Annales de Zootechine 36:341-342.
Van Niekerk, W.A., and N.H. Casey. 1998. The Boer goat. 2. Growth nutrient requirements, carcass and meat quality. Small Ruminant Research 1:355-368.

Wahid, A., H. Rozimah and S.K. Koh. 1985. Introduction of Sannen to Anglo-Nubian $\times$ local and Jamunapari $\times$ local cross-bred goats, carcass characteristics. Proceedings of the $9^{\text {th }}$ Annual Conference, Malaysian Society of Animal Production, held at University Pertanian, Selangor, 11-12 March 1985, pp 27-31. 